\title{
A Study on the Effects of Strategic HRM Systems on Performance: The Case of Pakistani Manufacturing Companies.
}

\author{
Robina Yasmin \\ (Graduate School of Management, Aichi Gakuin University)
}

\begin{abstract}
This study explores the relationship between HRM (human resource management) systems and performance using data from 192 manufacturing companies operating in Pakistan. This study examines this relationship in two ways: direct impact of HRM systems on performance and indirect impact or effect of HRM systems on performance through HR outcomes. The HRM systems include the practices of participative leadership, job security and training and development. The results of regression analysis suggest that the individual HRM practices impact the performance significantly in isolation but these direct effects are insignificant when HR outcomes mediate the relation between HRM systems and performance. The configuration of HRM practices showed a significant impact on performance. These impacts are more profound when management uses HRM practices to elicit the employee's attitudes/behaviors in terms of job satisfaction and work motivation. The results of structural equation modeling also suggest the prediction that the HRM systems impact performance more significantly through HR outcomes. Hence the study emphasizes the systematic and integrated use of behavior oriented HRM practices in order to achieve competitive advantage.
\end{abstract}

Keywords: strategic HRM systems, HR outcomes, Pakistani companies, configuration approach, mediation perspective.

\section{INTRODUCTION}

With a rapidly changing economic environment, businesses all over the world are facing new trends of globalization and free market. Organizations in the new economy are facing strong competition. Major challenges for organizations in future are more urgent search for competitive advantage. In order to be efficient and competent organizations must continually improve their performance by reducing cost, innovating products and processes, and improving quality, productivity, and speed to market (Becker \& Gerhart, 1996). Human resource management (HRM) systems of an organization can be a source of sustained competitive advantage. The previous studies clearly reveal that the HRM practices, applied in a systematic and integrated manner, are associated with positive performance outcomes, (Appelbaum et al, 2000; Berg, 1999; Huselid, 1995) and higher financial success (Huselid, 1995).

HRM in Pakistani companies has been adapted to meet these challenges and to speed up the pace of economic and business activities. The HRM system of Pakistani companies is in its developing phase. Many organizations have titled their Personnel and Administration departments as HR departments while frequently practicing reactive HRM. It is argued (Khilji, 2001) that the HRM practices in Pakistani companies are not applied in a systematic and integrated way. As a result, problems are compounded. No organization claims to be free from HR problems such as low motivation, lack of commitment and high turnover in employees. The organizational structure is bureaucratic, centralized and control oriented.

There are very few organizations that have adopted a systematic approach to HRM systems. With the opening up of economy and large inflows of foreign direct investment (FDI), new and fresh perspective to management systems are added. Top management and HR departments are becoming accessible as an open door policy is being adopted. As a result, a new pattern of HRM is evolving in several private sector organizations. It is interesting to explore the transformation in the HRM practices/policies.

The purpose of the present article is to empirically examine the relationship of perceived HRM prac- 
tices to organizational performance in companies operating in developing countries like Pakistan. Although there are a large number of literature and research on the link between HRM and performance, these are mostly related to developed countries such as USA and UK. Research on HRM systems of developing countries like Pakistan is scarce. Researchers suggest that more HRM studies should be conducted across more diversified cultures and nations (Budhwar \& Debrah, 2001). Moreover, the findings of the study can be a source of knowledge and may have practical implications for the developing countries' businesses.

\section{RESEARCH FRAMEWORK}

\section{HRM and Performance}

A wide range of research and the majority of HRM professionals accept that organizational human resource management policies can, if properly configured, provide a direct and economically significant contribution to firm performance. Empirical studies explained a strong and direct relationship between the quality of HRM practices and return on shareholder investment. These results are also found to be valid in companies outside America (Bae \& Lawler, 2000).

Scholars from different disciplines have presented various conceptual frameworks to explain the nexus between a firm's HRM systems/practices and performance. The most prominent ones among these are general systems theory (Von Bertalanffy, 1950), role behavior theory (Katz \& Khan, 1978), institutional theory (Meyer \& Rowan, 1977), resource dependency theory (Pfeffer \& Cohen, 1984), human capital theory (Becker, 1964), agency theory (Jensen \& Meckling, 1976) and resource-based theory (Barney, 1991). All these theories have a consensus on the significant impact of HRM practices in the determination of employee's and firm's performance. A review of all these theories is beyond the scope of this study. However, this particular study analyzes the relationship between HR systems and firm's performance using the concept of resourcebased theory. According to Koch \& McGrath (1996), the resource-based perspective offers a useful basis for understanding why human resource management makes a potential contribution to performance at the firm level.

The resource-based approach stresses the need for a specific HRM strategy, which seeks to achieve competitive advantage by increasing the efficiency and competency of the work force. Barney (1991) argues that sustained competitive advantage can be achieved by acquisition and effective use of bundles of distinctive resources that competitors cannot imitate. MacDuffie (1995) contends that human resources can be a primary source of sustainable competitive advantage for a firm. Employee's knowledge about products, processes and customers that is embedded in routines and social interaction patterns can create organizational capabilities more difficult to imitate than readily purchased technological capabilities. An organization's HR strategies, policies and practices are unique blend of processes, procedures, styles, capabilities and organizational culture (p.198).

In an attempt to examine the link between HRM strategy and performance, Delery and Doty (1996) explained that there are three approaches to understand this relationship: the universalistic perspective, the contingency perspective, and the configurational perspective. Universalistic perspective maintains that some HRM practices are better than others and most organizations should adopt these best practices. Because of globalization and increasing competitive pressure, HRM practices converge to a universalistic approach. These practices are called high performance work practices or best practices. Osterman (1994), Pfeffer (1994) and Huselid (1995) supported and used the universal perspective in their research. Several other empirical studies also support this approach (Delery and Doty, 1996).

Contingency approach posits that an organization's HRM practices must be consistent with other aspects of organization in order to be effective (LengnickHall \& Lengnick-Hall, 1988; Schuler \& Jackson, 1987). According to this approach performance is enhanced if an organization maintains a greater congruence between its strategies, external and internal environment, etc. and HR practices.

Configurational approach tries to build unique patterns or combinations of HRM practices with maximum performance. This approach insists that to be successful, an organization must develop HR systems that achieve internal consistency of its HRM practices (horizontal or internal fit) and congruence of HR system with its strategy (vertical or external fit). Confguration- 
al theories are different from the universalistic and traditional contingency theories. The configurational theories are based on the holistic approach; ideal types (or more sophisticated types) of HRM practices and policies; and the systems assumption of equifinality. Delery and Doty (1996) further describe that "the configurational theories are concerned with how the pattern of multiple independent variables is related to a dependent variable rather than with how individual independent variables are related to a dependent variable" (p.804).

This study tries to examine the link between HRM practices and performance in two ways: direct link (i.e. universal approach and configuration approach) and indirect link between HRM practices and performance or when HR outcomes mediate the relation between HRM practices and performance (i.e. mediation approach). The universal approach is a simple and most widely used approach. However, the configuration approach does not have much empirical evidence in developing countries like Pakistan. Snell et al (1996) argue that the configuration approach is very useful in creating sustained competitive advantage, as the combination of various HRM practices may help facilitate organizational learning, adaptation and renewal. In this way HR systems and people create the competitive advantage. However, it is not possible that any one of these practices leads to sustained competitive advantage. Wright \& McMahan (1992) further stress that multifunctional system of HRM practices may provide firms with a source of sustained competitive advantage if they possess three characteristics: HR practices create value, are casually ambiguous and are socially complex. For instance, it is easy to copy an individual HRM practice like firm's career development program. But it is more difficult to duplicate a whole HR system consisting of different HRM practices like participation, appraisal, feedback, career development, compensation program, etc.

\section{RESEARCHDESIGN}

It is now a widely accepted notion that HRM practices contribute to firm's performance through some intervening factors referred to as HR outcomes. Many scholars have advocated that relating HR systems directly to firm's performance is shortsighted and proposed different models explaining the indirect link between HRM practices and firm's performance. Beer et al. proposed competence, commitment, congruence and cost effectiveness as intermediary variables. Becker \& Huselid (1998) identified the mediating variables such as employee skills, employee motivation, job design and work structure link to operating performance, which in turn influence the profit and market value. Ferris et al presented a social context model that described organizational climate, employee attitudes and behaviors as intervening factors. Chadwick and Cappelli (1999) following the resource-based view proposed that HR systems may lead to higher performance by developing and exploiting the key internal capabilities that lead to sustained competitive advantage.

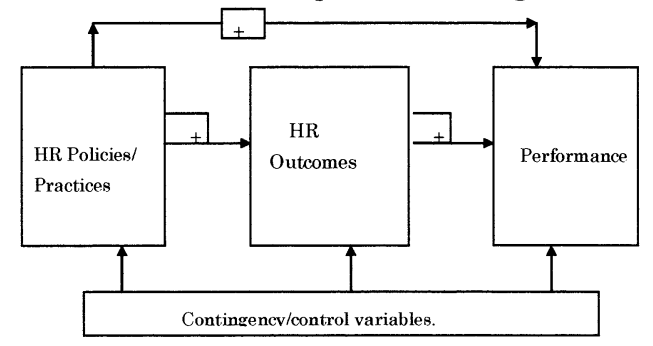

Source: Paauwe (2004, p. 56).

Figure 1: General Overview of the Linkages between HR Activities, Outcome and Performance.

According to Guest (1995), any analysis of influences on company profits quickly leads to the conclusions that factors other than HRM are involved. He further describes that in understanding the relationship between HRM practices and performance, it is assumed that improved performance is achieved through the people in the organization. Guest (1987) presented a normative model explaining the linkage between HRM activities, outcomes and performance. Paauwe and Richardson (1997) summarized the Guest' s normative model in Figure 1. This model (Figure 1) acknowledges the role context variables, but main thing this model stresses is that the HRM practices should be designed to lead to HRM outcomes of employee's attitudes and behaviors. The Figure 1 presents that there are two ways to explain the relationship between HRM polices/practices and performance. One way is the direct impact of HRM practices on performance and the other is the impact of HRM practices through HR outcomes. In this study it is assumed that the employee' $\mathrm{s}$ 
behaviors and attitudes are mediating the relationship between HRM practices and firm's performance. This study examines the relation between HR system and performance using both perspectives i.e. direct link between HR system and performance, and indirect link between HR system and firm's performance.

\section{HYPOTHESES}

\section{Direct Linkage between HR Practice and Perfor- mance}

\section{The case of universal prediction}

Participative Leadership Style: Research has shown that participation increases both employee job satisfaction and productivity. Fernie et al. (1994) found that employee involvement practices have a positive influence on productivity and product quality. He further states that employee involvement results in better social climate. Huselid \& Becker (1995) surveyed the performance and work practices of 222 firms and reached the conclusion that participative practices are significantly associated with decreased turnover, increased productivity and improved financial performance.

G. Cole (2002) says that the reason for encouraging greater employee involvement and participation in decision-making is that it can lead to improved efficiency and effectiveness in delivering goods and services to customers. If the means of participation not only increases employee's contribution to problem analysis (which may bring a sense of recognition to individuals), but also enhances their ability to make important operational decisions, then increased employee's job satisfaction and motivation are likely. This in turn leads to better product and service quality and enhances customer satisfaction. Thus, there are sound practical reasons for finding ways of increasing the involvement of ordinary employees in the day-to-day running of an organization. Here it is proposed that participation of employees will lead to the higher performance of organization.

Hypothesis 1.1: The practice of participative leadership will lead to higher level of organizational performance.

Job Security. It is widely accepted that the practice of employment security has direct effect on the behavior of employees. According to Appelbaum et al. (2000), employment security is positively related to productivity, employee trust, and organizational commitment. It is argued that employment security is prerequisite for most of high performance practices, such as selective hiring, extensive training, information sharing and delegation. The firm will not invest heavily in careful screening and training of new employees if these employees are not expected to stay with the firm for a long term to reap these investments. Most research on the effects of high performance management systems has incorporated employment security as one important dimension. This is because the innovations in work practices or other form of worker management cooperation or productivity improvement are not likely to sustain when workers fear that they will lose jobs as a result of increased productivity (Pfeffer, 1998). It is argued that provision of job security encourages employees to work harder. Ichniowski and associates (1994) noted workers will only spend extra effort if they expect a lower probability of future layoffs.

Hypothesis 1.2: The practice of job security will result in higher level of performance.

Training and Development. Training is an essential component of high performance work systems (Pfeffer, 1998), because these systems rely on front line employee skill and initiative to identify and resolve problems, to initiate changes in work methods, and to take responsibility for quality. All of this requires skilled and motivated work force that has the knowledge and capability to perform the requisite tasks. Organizations can improve the quality of current employees by providing comprehensive training and development activities (Delaney \& Huselid, 1996). Koch \& McGrath (1996) suggest that company-sponsored training and development programs often increase the firm specific skills of employees. In this way it decreases the likelihood that other firms would deploy these trained workers in the same productive way. Becker (1996) argues that some kinds of training are equally useful to a firm and to its competitors. In such cases, the company offering training pays cost and competitors are subsidized, if these trained workers are hired away by them. In response to this argument, resource-based theory suggests that firm specific routines make it impossible that an employee trained in one company would be of equal use at the same price in another.

A large number of studies provide evidence that investment in training leads to beneficial organizational outcomes. Appelbaum et al. asserted in a study 
(2000) that formal and informal training are positively related to employee trust and intrinsic motivation. Boselie et al. (2001) asserted that training and development are positively related to trust in decision-making and perceived employee job security. Training has positive impact on perceived organizational performance (Delaney \& Huselid, 1996).

Hypothesis 1.3: Training and development programs of the company have significant impact on its performance.

\section{The case of configurational prediction}

HRM practices are associated with positive performance outcomes and higher financial success (Huselid, 1995; Lawler et al., 1995). It is argued that the nexus between HRM and performance becomes stronger and pronounced when the HR practices are implemented together as a system or in a holistic manner. The researchers who favor this approach call for the HRM policies and practices which are internally aligned, in order to gain higher performance. According to Guest (1997), this approach requires a set of internally consistent HRM practices, in other words an internal fit of HRM practices. Internal fit refers to the extent to which the components of HR are logically connected and supportive for one another. There may be a number of possible combinations or configurations of practices which lead to higher performance.

Guest (1997) describes two ways to test the combined impact among HRM systems, named as fitas-bundle and fit-as-gestalt. The fit-as-bundles implies that multiplicative pattern or an interaction of particular pattern of HRM practices brings out the synergic effects on performance. The fit-as-gestalt approach is based on three assumptions: 1) the sum of each HRM practice is greater than its parts; 2) the pattern of combinations among HRM practices is additive rather than multiplicative; and 3) one key aspect of HRM is needed. The multiplicative approach is more complex and rigid, which implies that if any single HRM practice is missing, the bundle score or the effect should be zero. In the additive approach the HRM practices are interrelated but the absence of any particular HR practice will not remove the effect of all other practices. For this reason, in this study the additive approach is followed. MacDuffie (1995) and Osterman (1994) take this approach in their research. Interactions between bundles can also be tested in two ways that are multiplicative and additive. According to MacDuffie (1995) the multiplicative method is better due to the assumption of complementarities between bundles.

To date, studies related to the impact of $\mathrm{HR}$ practices on performance vary significantly in terms of which practices to be included in the analysis. For example, Arthur's (1994) high performance employment system has given less emphasis to the variable pay. Huselid (1995) and MacDuffie (1995) in their analysis have given strong emphasis on variable pay. Huselid (1995) and Pfeffer (1994) have described such practices as high performance. The notion that which practices should be configured to achieve performance needs clarification. In this particular study it is proposed that an organization can experience superior performance if it adopts high performing management practices such as participative leadership, job security and training and development.

H2: The particular pattern of internally consistent HRM practices (here referred to as Participative HRM, Job security and Training and Development) will significantly impact organizational performance.

\section{Indirect Linkage between HR Practice and Per- formance}

\section{HRM practices influence HR outcomes}

The behavioral perspective (Jackson et al. 1989) implies that successful implementation of strategic HRM practices depends heavily on employee's behavior. It is argued that in order to achieve lasting results and to contribute effectively to the success of their company, employees must be motivated and satisfied (Becker \& Wilson, 2000; Fey et al, 2000; Guest, 2001). This behavioral change is possible if a firm applies a systematic set of high performance HRM practices. Organizational HR polices and practices result in certain HR outcomes like high level of job satisfaction, and work motivation which lead to more efficient workforce, This efficient and competent workforce contribute positively to the achievement of business objectives. For example, the retention-oriented practices like job security will have a positive effect on the employee's behavior. Training not only ensures that employees and managers can perform their jobs compe- 
tently, but also demonstrates the firm's commitment to its employees (Kleiman, 1997). The employees can be terminated due to lack of their job skills or competence due to low motivation or job satisfaction. Training can prevent unnecessary termination by improving employee' s behavior or harnessing the employee' s motivation. Some employees, often the best ones, choose to leave an organization because they are not satisfied with the way company manages its employees. A company' $\mathrm{s}$ training and development practices can help to alleviate this problem. Organizations can modify the behavior of those who practice ineffective management styles through instructional programs. Appelbaum et al. (2000) found in a study that formal and informal training are positively related to employee trust and intrinsic motivation

Hypothesis 3.1: A positive relation exists between HRM practices and HR outcomes.

\section{HR outcomes influence performance significantly}

It is argued that to achieve lasting and better performance and to contribute significantly to the success of their organization, employee's behavior and attitudes must be supporting to the organizational objectives. If employees have good attitudes and behaviors, they are more likely to work for the benefit of the organization, thus positively affecting firm performance (Arthur, 1994). According to MacDuffie (1995), "Skilled and knowledgeable workers who are not motivated are unlikely to contribute any discretionary effort. Motivated workers who lack skill or knowledge may contribute discretionary effort with little impact on performance (p.199)" .

Hypothesis 3.2: HR outcomes (ie. employee's behavior) will significantly influence performance.
HRM practices influence performance through HR outcomes

Ostroff and Bowen (2000) and others (e.g., Delery \& Shaw, 2001; Becker \& Gerhart, 1996) note that relating organizational practices directly to outcomes is shortsighted and simplistic. The direct relation fails to recognize that the HRM practices themselves are not responsible for the change in outcomes. Rather the HRM practices must be translated in some way by the organization's employees to impact jobs and roles. Employees give meaning to the organizational policies through their attitudes and behaviors. Organizations cannot experience success, unless the employees respond effectively and positively to HR practices and policies.

Hypothesis 3.3: HR outcomes mediate the relationship between HRM practices and performance.

\section{RESEARCH METHODOLOGY}

In order to analyze the effect of HRM practices on employee's attitudes and on performance a questionnaire survey was conducted. In July 2005, 1000 questionnaires were mailed to HR managers of the manufacturing companies (both Pakistani owned and foreign owned companies) operating in Pakistan Regarding the size of companies, the companies with more than 50 employees were surveyed. After almost one year 240 questionnaires were responded and most of responses were received through personal connection (i.e. friends and relatives). Out of 240questionnaires 192 were usable, making the response rate 192\%. Most of the companies responded were Pakistani owned companies i.e. 171 and 21 multinational companies (MNCs) responded. (Table 1)

Table 1: Types of Companies Responded and their Demographic Characteristics:

\begin{tabular}{|l|l|l|l|l|l|}
\hline Types & Total no. & LC & MNCs. & No. of MNCs by parent country \\
\hline Food processing & 20 & 18 & 2 & 1 France, 1 Switzerland \\
\hline Chemical and Pharmaceutical & 29 & 18 & 11 & $\begin{array}{c}\text { 5 UK, 3 USA, 1 Austria, } \\
\text { 1 Germany, 1 Japan }\end{array}$ \\
\hline Textile & 67 & 67 & & \\
\hline Electrical appliances & 10 & 9 & 1 & 1 Germany \\
\hline $\begin{array}{l}\text { Construction materials } \\
\text { (Cement, ceramics, tiles, etc.) }\end{array}$ & 18 & 18 & & \\
\hline Auto parts and automobile & 15 & 11 & 4 & 4 Japan \\
\hline Steel products & 7 & 7 & & \\
\hline Engineering goods & 7 & 7 & & \\
\hline Thermal power plants & 7 & 6 & 1 & 1 Austria \\
\hline Sports goods & 7 & 7 & & \\
\hline FMCG (Fast moving consumer goods) & 2 & & 2 & UK \\
\hline
\end{tabular}




\section{MEASURES}

HR systems: Following the study of Delery and Doty (1996) the questionnaire was prepared consisting of three HRM practices including participative leadership (8 items), job security (5 items), and training and development (8 items). A five point Likert scale (very much disagree $=1$, neutral $=3$ and very much agree $=5$ ) was used to measure these HRM practices.

HR outcomes: The HR outcomes are measured through attitudes and behaviors of workers, measures used by other researchers like Tsui et al. (1997) and Katou \& Budhwar (2006). However, in this study the mediating variables are measured by the perceived rating of the organization's HR outcome measures following the Katou \& Budhwar (2006, p.1232). It is acknowledged that the study might be affected by the common method bias, as the single source (i.e. HR manager) provides data on HR policies, HR outcomes and organizational performance. The data for the change in employee's attitudes (HR outcomes) that is based on HR manager's perception may not truly represent the employee's feelings. However, it is expected that the common method bias may be limited in this study because the sample size is large (Cooper and Emory, 1995).

The behavioral consequences of these HRM practices included two aspects of HRM outcomes, namely, employees work motivation and job satisfaction. The HR manager was asked how he perceives the change in job satisfaction and work motivation of their employees during past three years. These two factors were also measured by using the 5-point Likert scale.

Performance: The financial performance measure was based on three self-report variables, namely, quality, profit and revenue using the methodology of Delaney and Huselid. It is noted that the research up till now has been based on both objective and subjective indicators of performance. From previous researches, (Guest, 2003; Guthrie, 2001), it is evident that subjective data may be as valid as objective measures. The respondents were asked how they perceive their performance in terms of quality, profit and revenue for last three years. For measurement the same 5-point Likert scale was used.

Statistical Procedures: In order to check that all items are internally consistent, factor analysis on all variables was conducted. After that, to check if variables are interrelated, correlations were calculated. To test the hypotheses and to examine the impact of variables on firm's performance and HR outcomes, multiple regression analyses were carried out. Finally, in order to check the structure or pattern of effects of HR systems on performance, structural equation modeling was performed.

\section{RESULTS}

\section{Correlation and Factor Analysis}

Factor analysis for HRM practice was calculated by principle component analysis using the Varimax rotation method. To check the internal reliability of the scale, Cronbach's alpha coefficient was used. The Cronbrach's alpha coefficients of 0.6 or higher are considered acceptable. Then, correlation among these factors was calculated to check whether these variables are interdependent or not.

Table 2: Correlation Matrix and Reliability Values:

\begin{tabular}{|l|l|l|l|l|l|}
\hline & Leadership & $\begin{array}{l}\text { Job } \\
\text { Security }\end{array}$ & $\begin{array}{l}\text { Training and } \\
\text { Development }\end{array}$ & $\begin{array}{l}\text { HR } \\
\text { outcomes }\end{array}$ & Performance \\
\hline Leadership & $(0.818)$ & & & & \\
Job Security & 0.042 & $(0.847)$ & & & \\
T\& D & $0.538^{* *}$ & -0.057 & $(0.791)$ & & \\
HR outcomes & $0.596^{* *}$ & -0.066 & $0.549 * *$ & $(0.758)$ & \\
Performance & $0.433^{* *}$ & 0.009 & $0.44^{* *}$ & $0.620^{* *}$ & $(0.679)$ \\
Mean & 11.062 & 4.896 & 10.115 & 6.901 & 11.365 \\
SD & 2551 & 1.414 & 3.219 & 1.633 & 1.685 \\
\hline
\end{tabular}

Note: "*p<0.01,"*p<0.001, (): Cronbach's alpha, SD: Standard deviation

Table 2 shows that all five factors produced alpha values of more than 0.6 , depicting that these factors are internally consistent. The correlation matrix also shows that all factors are significantly correlated except job security. The other HRM practices such as participative leadership and training and development are positively correlated with performance. The behavioral outcome of $\mathrm{HR}$ practices is also significantly correlated to participative leadership, training and development and performance.

\section{Multiple Regression Analysis}

Direct Linkages between HR Practices and Performance

In order to examine the impact of HR practices on performance, a hierarchical regression analysis was conducted. Table 3 shows the results of hierarchical regression analysis. The control variables, company size and age (marginally significant) fail to show 
Table 3: Results of Hierarchical Regression Analysis:

\begin{tabular}{|c|c|c|c|c|c|c|c|c|c|}
\hline \multirow{2}{*}{$\begin{array}{l}\mathrm{D} \\
\mathrm{V}\end{array}$} & \multirow{2}{*}{$\begin{array}{l}\text { Independent } \\
\text { variables }\end{array}$} & \multicolumn{2}{|c|}{ Model 1} & \multicolumn{2}{|c|}{ Model 2} & \multicolumn{2}{|c|}{ Model 3} & \multicolumn{2}{|c|}{ Model 4} \\
\hline & & B & Sig. & B & Sig. & B & Sig. & B & Sig. \\
\hline \multirow[t]{13}{*}{$\mathrm{P}$} & Age & 0.144 & .060 & 0.087 & .208 & 0.065 & .290 & 0.084 & .164 \\
\hline & Size & 0.110 & .147 & 0.051 & .455 & 0.071 & .240 & 0.081 & .169 \\
\hline & Lead. & & & 0.297 & .000 & 0.053 & .474 & -1.062 & .001 \\
\hline & JobSec. & & & 0.022 & .733 & 0.054 & .348 & -0.564 & .076 \\
\hline & $T \& D$ & & & 0.262 & .001 & 0.099 & .176 & -0.206 & .508 \\
\hline & HR outcomes & & & & & 0.523 & .000 & 0.521 & .000 \\
\hline & Lead*JobSec. & & & & & & & 1.201 & .005 \\
\hline & Lead*T\&D & & & & & & & 0.953 & .004 \\
\hline & JobSec. ${ }^{* T \& D}$ & & & & & & & 0.479 & .091 \\
\hline & $\mathrm{R}^{2}$ & \multicolumn{2}{|l|}{0.044} & \multicolumn{2}{|l|}{0.260} & \multicolumn{2}{|l|}{0.415} & \multicolumn{2}{|l|}{0.458} \\
\hline & Adjusted $\mathrm{R}^{2}$ & \multicolumn{2}{|l|}{0.034} & \multicolumn{2}{|l|}{0.240} & \multicolumn{2}{|l|}{0.396} & \multicolumn{2}{|l|}{0.431} \\
\hline & $\Delta \mathrm{R}^{2}$ & & \multicolumn{2}{|l|}{0.216} & & \\
\hline & $\bar{F}$ & & $4.330^{*}$ & \multicolumn{2}{|c|}{$18.139^{* * *}$} & \multicolumn{2}{|c|}{$\frac{0.100}{48.857^{* * * *}}$} & \multicolumn{2}{|c|}{$\frac{0.045}{4.781^{\star *}}$} \\
\hline
\end{tabular}

Note: $" p<0.05, " p<0.01, * " p<0.001$

DV: Dependent Variable, P: Performance, JobSec: job security, RS: R square

any significant impact individually on performance but their joint impact is significant $\left(\mathrm{F}=4.330^{*}\right)$.

Table 3 (Model 2) reveals that HR practices, leadership style and training and development, impact performance significantly in isolation (i.e. $\beta=0.297$, $\mathrm{p}<.001$ and $\beta=0.262, \mathrm{p}<.01$ respectively). The practice of job security shows the insignificant impact on performance. The reason may be that job security consists of only two factors (the company provides permanent jobs at the start and the company adopts lay off policy in bad economic conditions) that may influence job security in opposite directions. It may be needed to add some other influential factors to observe the job policy of the company. After controlling the effects of company age and size, the HR practices as a whole explained a significant impact on the performance of company. This can be viewed from the value of change in $\mathrm{R}$ square $\left(\Delta \mathrm{RS}=0.216\right.$ and $\mathrm{F}=18.139^{* * *}$ ). The change in $\mathrm{R}$ square reflects that overall, $21.6 \%$ of variation is explained by HR practices of participative leadership, job security and training and development. The results in Model 2 (Table 3) generally state that $\mathrm{HR}$ practices significantly impact performance. However, this is the case when the effect of HR practices on performance is evaluated in isolation (Model 2). In case HR outcomes are added to the model (i.e. Model 3, Table 3), the HRM practices coefficients are smaller and have become insignificant or we can say that with entering the other measures of HRM practices (here HR outcomes) the effects of individual HR practices are vanished. These results are consistent with the findings of Delaney \& Huselid (1996, p.962) and Ichniowski et al.
(1994) who found that the evaluation of individual HRM practices in isolation results in biased estimates and substantially overstate the effects. Considering the mediation perspective we can infer from Model 3 (Table 3 ) that the direct impact of HR practices on performance is insignificant and the hypotheses 1.1, 1.2 and 1.3 are rejected.

The model 4 (Table 3) presents the interaction effects of HR practices. The hypothesis 2 that the configuration of HR practices will reinforce the performance is supported. The interaction between participative leadership and job security has significant impact on performance as $\beta=1.201, \mathrm{p}<0.05$ and the interaction effects of participative leadership and training and development are also significant with $\beta=0.953, \mathrm{p}<$ 0.05 . However, the overall combined interactions showed a significant impact on the performance of a firm with $\Delta \mathrm{RS}=0.043, \mathrm{~F}=4.781^{* *}$. The interaction of HR practices produced $4.3 \%$ variation in the performance. This change in $\mathrm{R}$ square reveals that the hypothesis that configuration of HR practices/system will significantly impact performance is supported.

Table 4: Results of Hierarchical Regression Analysis:

\begin{tabular}{|c|c|c|c|c|c|}
\hline \multirow[t]{2}{*}{ DV } & \multirow{2}{*}{$\begin{array}{l}\text { Independent } \\
\text { Variables }\end{array}$} & Model 1 & & Model 2 & \\
\hline & & $\overline{\mathrm{B}}$ & Sig. & B & Sig. \\
\hline \multirow[t]{9}{*}{$\mathrm{HR}$} & Age & 0.126 & 0.104 & 0.042 & 0.489 \\
\hline & Size & 0.035 & 0.649 & -0.039 & 0.507 \\
\hline & Lead. & & & 0.432 & 0.000 \\
\hline & JobSec. & & & -0.061 & 0.276 \\
\hline & T\&D & & & 0.311 & 0.000 \\
\hline & $\mathrm{R}^{2}$ & 0.020 & & 0.435 & \\
\hline & Adjusted R ${ }^{2}$ & 0.010 & & 0.420 & \\
\hline & $\Delta \mathrm{R}^{2}$ & & & 0.415 & \\
\hline & F & 1.93 & & $45.531^{\star \star *}$ & \\
\hline
\end{tabular}

Note: " $p<0.05, " p<0.01, " p<0.001$

DV: Dependent Variable, HR: HR outcomes, JobSec: job security, RS: R square. 
A Study on the Effects of Strategic HRM Systems on Performance: A Case of Pakistani Manufacturing Companies.

Indirect Linkages between HR Practices and Performance

Next, Hypothesis 3.1 that HR practices will lead to HR outcomes in terms of employee's attitudes was partially supported. Table 4, Model 2 reflects the effects of HR systems on HR outcomes. The practices of participative leadership and training and development show a significant impact on HR outcomes with $\beta=0.432, \mathrm{p}<.001$ and $\beta=0.311, \mathrm{p}<.001$ respectively. It is worth to note that the joint impact of HR systems shows the highest variation in adjusted $\mathrm{R}$ square i.e. $\Delta$ $\mathrm{RS}=0.415, \mathrm{~F}=45.531^{* * *}$. Whereas these HRM practices as a whole show comparatively less increment in performance in terms of adjusted $R$ square $(\Delta R S=$ $\left.0.216, F=18.139^{* *}\right)$. The HR practices showed a variation of $41.5 \%$ on employee's attitudes and behaviors. This confirms the hypothesis that HR systems have significant impact on the HR outcomes.

Hypothesis 3.2 that the HR outcomes will significantly impact the performance of company was also supported. From Model 3 in Table 3, it can be observed that the HR outcomes show the highest beta value i.e. $\beta=0.523, \mathrm{p}<.001$. The change in performance by HR outcomes can be examined from the value of change in $R$ square which is: $\Delta R S=0.155, F=48.857^{* * *}$. Variation produced by HR outcomes after removing the effect of other variables is $15.5 \%$. Model 4 in Table 3 also shows when HR outcomes are added in the model, it has affected the beta values and significance level of HRM practices. The individual impact of all HR practices be- comes insignificant in the presence of HR outcomes, which strongly supports the view that analysis of individual HR practices lead to substantially larger coefficient (Delaney \& Huselid, 1995).

Hypothesis 3.3 that the HR outcomes mediate the relationship between HR practices and performance is also supported. It was assumed that if the organization tries to illicit the motivation of employees through progressive HR systems, it will significantly impact performance. The results show that employee's attitudes are quite an important factor to impact the performance. The hypothesis 3.3 was also tested by structural equation modeling.

\section{Structural Equation Modeling}

In order to test the hypothesis 3.3 that the HR outcomes mediate the relation between HR practices and performance, structural equation modeling (SEM) was done. Figure 2 explains that the practices of participative leadership and training and development have a significant impact on employee's attitudes, whereas these practices have an insignificant direct impact on performance.

Figure 2 is consistent with Model 3 in Table 3. Hypothesis 3.3 assumes that the HR practices will impact the performance through HR outcomes. The practice of participative leadership has a significant impact on job satisfaction and motivation of employees with $\beta=0.457, \mathrm{p}<.001$. Training and development also showed a significant impact on the attitudes of

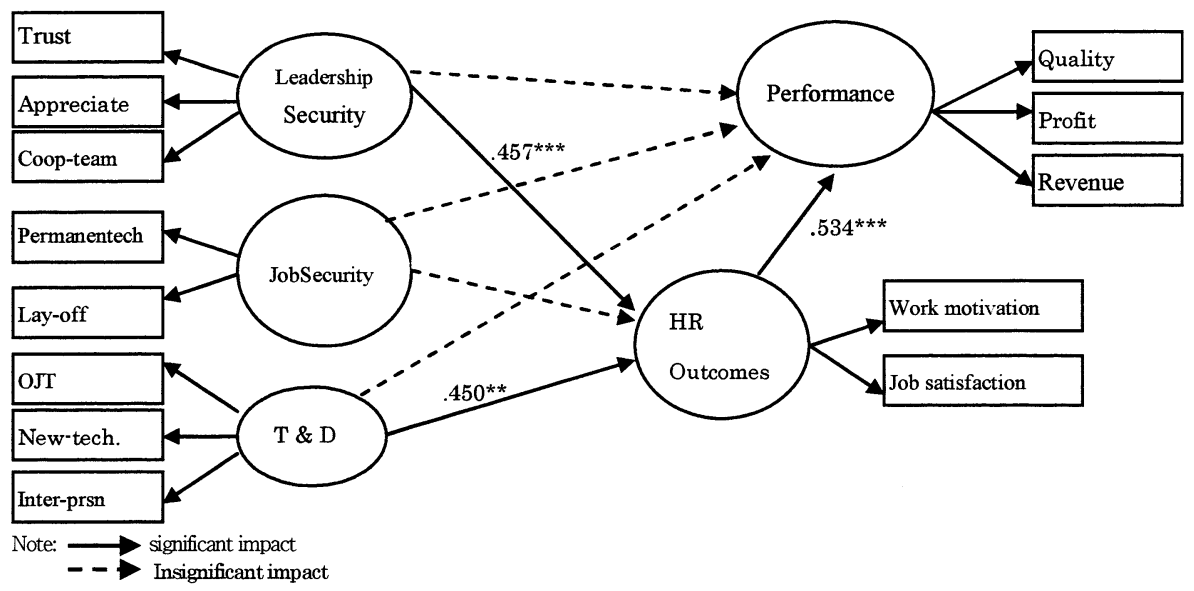

Note: " $" \mathrm{p}<.01, " \mathrm{p}<.001$; GFI: 0.921: CFI: 0.941: RMR: 0.052; AGFI: 0.870; RMSEA: 0.072

Coop-team: cooperative team work, New-tech: new technology, Inter-prsn: interpersonal skill,

T\&D: training and development.

Figure 2: Structural Equation Modeling 
workers ( $\beta=0.452, \mathrm{p}<.005$ respectively). In the presence of HR outcomes the individual HR practices have insignificant impact on performance. The HR outcomes show the strongest impact with $\beta=0.534, \mathrm{p}<0.001$. This positive behavior of employees in terms of job satisfaction and work motivation reinforces the performance. Thus, the hypothesis that HR practices will influence performance through HR outcomes is supported. The organization can significantly impact the performance, if they first try to change the behavior of employees.

Goodness of fit tests determines whether the model presented should be accepted or rejected. There is a wide disagreement among researchers which fit indexes to report. Jaccard and Wan (1996) recommend the use of at least three fit tests. GFI is the goodness of fit index and its value varies from 0 to 1 . By convention, GFI should be equal to or greater than 0.9 to accept the model. Here, GFI is 0.92 , which means the model is acceptable. The RMR represents the root mean square residuals and for a well fitted model RMR should be equal to 0.05 or less. Here in this model RMR is 0.052 , which again shows that the model is acceptable. RMSEA i.e. the root mean square error of approximation should be 0.08 or less for an adequate fit. In this particular case RMSEA is 0.072 which is below 0.08 . Again this fit measure reveals that the model is acceptable. $\mathrm{P}(\mathrm{CMIN})$ explains the minimum sample discrepancy or chi-square index and by criterion it should be greater than 0.05 in order to accept the model. Here $\mathrm{P}(\mathrm{CMIN})$ is less than 0.001 , revealing that the present model is rejected as being a perfect fit. Many researchers have argued that chi-square can be misleading in the case of large size samples. In the case of the present model, as other fit indexes (GFI, RMR and RMSEA) have revealed the model is acceptable, the chi-square index may be misleading because of its sensitivity to sample size.

\section{DISCUSSION}

The purpose of this study was to find out the empirical evidence that HR systems, applied in a systematic way, can lead to superior organizational performance in developing countries like Pakistan. To date, only theoretical importance is given to these assertions in these countries. There is also lack of substantial em- pirical research in this field.

This study suggests that in isolation, progressive HR practices, participative leadership, and training and development, impact performance significantly. Most of the companies surveyed expressed that they encourage and appreciate the participation of workers in decision-making processes and promote the practice of team-work. In the case of training and development, a majority of companies provide on the job training to workers at the start of new job. They also provide training when new technology is introduced. Only job security has shown less significant explanatory value. To explain the predictor's value significantly, we might need to take into account the effects of industry type, economic conditions and labor market structure. One important reason for this might be that most of the companies in Pakistan (surveyed) adopted the layoff policy during the bad economic seasons. Also, some companies had seasonal nature of business (e.g. textile industry and food processing industry). An important point to note is that although the individual impact of job security is insignificant, the combined impact of all HR practices is significant. The combined HRM practices have brought about $21.6 \%$ change in performance. While taking into account the mediation perspective in Model 3 in Table 3 the individual effects of HR practices become insignificant. These findings support the view of Delaney \& Huselid (1996) who mention that "when HRM practices measured individually in our analysis, their estimated coefficients were always larger (often substantially larger) than their coefficients in the model containing other HRM practices measures" (p. 966).

The interactions between HRM practices also showed a significant impact on performance, supporting the configuration preposition. The interaction of HRM practices have explained $4.3 \%$ increment in performance and thus support the view that configuration of HR practices reinforce performance.

This study shows that these impacts of HRM systems are most significant and profound when management adopts a behavioral HR policy. Based on the estimates provided by the HR managers, the participative HRM practices have showed a $41.5 \%$ change in the employees' attitudes, suggesting that the progressive HRM practices including participative leadership and 
training and development have significant impact on employees' job satisfaction and motivation. The HR outcomes have brought $15.5 \%$ change in performance. Further, this study also verifies the findings of such researchers as Ostroff and Bowen (2000), Delery \& Shaw (2001) and Becker \& Gerhart (1996) who note that relating organizational practices directly to outcomes does not explain the causalities involved. According to them the HR policies and practices do not directly result in performance but these HR policies bring out changes in employees' attitudes and behaviors by impacting their jobs. These behavioral outcomes significantly impact productivity.

The empirical results presented support the view that an effective and integrated HR policy can provide a competitive edge to Pakistani companies. The past research has pointed out that HRM in Pakistan is hierarchical and control oriented, resulting in low level of participation and trust between management and employees. Training and development of employees is considered as cost and little importance is given to training and development (Khilji, 1999).This HR system has resulted in low level productivity, low quality of products and hence lower performance. Still from the findings of this study it is evident that manufacturing companies who have adopted progressive HRM practices in a systematic and integrated way are experiencing the significant impact in the employee's behavioral outcomes such as job satisfaction and motivation. This has led to significant variations in the overall performance of the companies. The important thing is to adopt the HR practices in a way that leads to positive behavioral outcomes.

The findings of this study, however, cannot be generalized and its results should be taken cautiously. The major limitation is that the single source (HR manager) provided information on HR practices, HR outcomes and perceived organizational performance. Specifically, the data for the change in employee's attitude based on the HR manager's observation may not truly represent the workers feelings. For further study it is stressed that to measure changes in employee's attitudes and behavior, employee's own response should be obtained. However, it is expected that the respondent bias is minimum due to large sample size and the nature of this study is assumed to be highly exploratory.
Another limitation is that this study takes into account one type of industries i.e. manufacturing. Future research on this topic should use multiple respondents and a broad range of organizations, so that the results can be generalized. This study is limited to the internal fit or the fit between HR practices. Further research is encouraged, regarding vertical fit or the fit between company's strategy and its HR systems. In spite of all these limitations this study makes an important contribution in the developing countries context and provides support to the configuration and mediation perspective.

\section{REFERENCES}

Appelbaum, E., Bailey, T., Berg, P. \& Kalleberg, A. 2000 Manufacturing advantage. Ithaca, NY: IR Press.

Armstrong, M. 2001 A handbook of human resource management practice. $8^{\text {the }}$. Kogan Page Limited.

Arthur, J. B. 1994 Effects of human resource systems on manufacturing performance and turnover. Academy of Management Journal, 37, 670-687.

Bae, J. \& Lawler, J. J. 2000 Organizational performance and HRM in Korea: Impact on firm performance in an emerging economy. Academy of Management Journal, 43, 502-17.

Baird, L., \& Meshoulam 1988 Managing two fits of strategic human resource management. Academy of Management Review, 13, 116-128.

Barney, J. 1991 Firm resources and sustained competitive advantage. Journal of Management, 17(1),99120.

Barney, J. 1995 Looking inside for competitive advantage. Academy of Management Executive, 9(4), $49-61$.

Baron, R. M., \& Kenny, D. A. 1986 The moderatormediator variable distinction in social psychological research: Conceptual, strategic and statistical considerations. Journal of Personality and Social PSychology, 51, 1173-1182.

Becker, B. \& Gerhart, B. 1996 The impact of human resource management on organizational performance: Progress and prospects. Academy of Management Journal, 39(4), 779-801.

Becker, K. \& Wilson, C. 2000 Development of affective organizational commitment: A cross sequential examination of change and tenure. Journal of Vocational Behavior, 56, 114-36. 
Boselie, et al. 2001 Human resource management and performance: Commitment oriented work systems through the eyes of employees. Paper presented at the annual meetings of the Academy of Management, Washington, D. C.

Brown, C., Reich, M. \& Stern, D.1993 Becoming a highperformance work organization: The role of security, employee involvement and training. The International Journal of Human Resource Management, 4(2), $247-275$

Byrne, B. M. 2001 Structural equation modeling with AMOS: Basic concepts, application and programming: New Jersey: Lawrence Erlbaum Associates Inc. Publishers.

Chadwick, C. \& Cappelli, P. 1999 Alternatives to generic strategy typologies in strategic human resource management. In Wright, P., Dyer, L., Boudreau, J \& Milkovich, G. (Eds.) Research in Personnel and Human Resource Management Greenwich, CT:JAI Press.

Christine, R., Vandenberg, R., \& Richardson, H. A. 2005 Employee involvement climate and organizational effectiveness. Human Resource Management, 44(4), 471-488.

Cole, G, 2002 Personnel and human resource management ( $5^{\text {th }}$ ed.). London: Letts Educational

Cooper, D.R. \& Emory, C. W. 1995 Business Research Methods. Chicago: Irwin.

Delaney, J. T. \& Huselid, M. A. 1996 The impact of human resource management practices on perceptions of organizational performance. Academy of Management Journal, 39(4), 949-69.

Delery, J. \& Doty, D. H. 1996 Modes of theorizing in strategic human resource management: Tests of universalistic, contingency and configurational performance predictions. Academy of Management Journal, 39(4), 802-35.

Budhwar, P. \& Debrah, Y. A. 2001 Human resource management in developing countries. London: Routledge.

Delery, J. \& Shaw, J. D. 2001 The strategic management of people in work organizations: Review, synthesis, and extension. Paper presented at the annual meetings of the Academy of Management, Washington, D. C.

Evans, P. A. L. 1986 The strategic outcomes of human resource management. Human Resource Management, 25(1), 149-167.

Fernie, S., Metcalf, D., \& Woodland, S. 1994 What has human resource management achieved in the workplace? Employment Policy Institute Economic Report 8-3.

Fey, C. F., Bjorkman, I \& Pavlovskaya, A. 2000 The effect of human resource management practices on firm performance in Russia. International Journal of Human Resource Management, 11: 1-18.

Garson, D. G. 2006 Structural equation modeling: At http:/www2.chass.ncsw/garson/pa765/structure.h tm.

Guest, D. E, Michie J., Conway N., \& Sheehan M. 2003 Human resource management and corporate performance in the UK. British Journal of Industrial Relations: 41(2), 291-314.

Guthrie, J. 2001 High involvement work practices, turnover and productivity: Evidence from New Zeeland. Academy of Management Journal, 44, 180-190.

Guest, D. E. 1997 Human resource management and performance: A review and research agenda. The International Journal of Human Resource Management, 8, 263-276.

Guest, D. E. 1987 Human resource management and industrial relations. Journal of Management and Industrial Relations, 24(5), 503-521.

Huselid, M.A. 1995 The impact of human resource management practices on turnover, productivity and corporate financial performance. Academy of Management Journal, 38(3), 635-672.

Huselid, M. A. \& Becker, B. 1995 High performance work systems and organizational performance. $\mathrm{Pa}-$ per presented at the annual meetings of the Academy of Management, Vancouver.

Ichinowaski, C., Shaw, K. \& Prennusi, G. 1994 The effects of human resource management practices on productivity. Working Paper, Columbia University.

Jaccard, J. \& Wan, C. K. 1996 LISREL approaches to interaction effects in multiple regression. Thousand Oaks, CA: Sage Publications.

Jackson, S. E. \& Schuler, R. S. 1995 Understanding human resource management in the context of organization and their environments. In Poole, M. (Eds.) Human resource management: Critical perspective on business and management (1999). 
A Study on the Effects of Strategic HRM Systems on Performance: A Case of Pakistani Manufacturing Companies.

Jackson, S. E., Schuler, R. S. \& Rivero, J. C. 1989 Organizational characteristics as predictors of personnel practices. Personnel Psychology, 727-786.

Jenson, M. C. \& Meckling, W. 1976 The theory of the firm: Managerial behavior, agency costs, and ownership structure. Journal of Financial Economics, 3: 305-36.

Katou, A. A. \& Budhwar, P. S. 2006 Human resource management systems and organizational performance: A test of a mediating model in the Greek manufacturing context. International Journal of Human Resource Management, 17: 7, 1223-1253.

Katz, D. \& Kahn, R. L. 1978: The social psychology of organizations. New York: Wiley.

Kenny, D.A. 2003 Mediation. Online at: http://users.cn.com/dakenny/mediate.htm.

Khilji, SE. 2001 Human resource management in Pakistan. In Budhwar, P. and Yaw, D. (Eds.) Human resource management in developing countries. London. Routledge.

Kleiman, L. S. 1997 Human resource management: $A$ tool for competitive advantage. Minneapolis/St. Paul: West Publishing.

Koch, J. \& McGrath, R. 1996 Improving labor productivity: Human resource policies do matter. Strategic Management Journal, 17, 335-354.

Lado, A. A., \& Wilson, M. C. 1994 Human resource systems and sustained competitive advantage: A competency-based perspective. Academy of Management Review, 19, 699-727.

Lawler E. E. 2005 From human resource management to organizational effectiveness. Journal of Human Resource Management, 44(2), 165-169.

Lengnick-Hall, C.A. \& Lengnick-Hall, M. L. 1988 Strategic human resource management: A review of literature and proposed typology. Academy of Management Review, 13, 454470.

Likert, R. 1967 The human organization: Its meaning and values. New York: McGraw Hill.

MacDuffie, J. P. 1995 Human resource bundles and manufacturing performance: Organizational logic and flexible production systems in the world auto industry. Industrial and Labor Relations Review, 48, 197-221.

Mathis, R. L., \& Jackson, J. H. 1995 Personnel human resource management. Minneapolis/St. Paul: West
Publishing.

Meyer, J. \& Rowan, B. 1977 Institutionalized organizations: Formal structures as myth and ceremony. Reprinted in W. W. Powell and P. J. DiMaggio (Eds): The new institutionalism in organizational analysis. Chicago: University of Chicago Press, 1991.

Miles, R. 1965 Human relations or human resources. Harvard Business Review, 43, 148-163.

Osterman, P. 1994 How common is workplace transformation and who adopts it? Industrial and Labor Relations Review, 47, 173-188.

Ostroff, C., \& Bowen, D. E. 2000 Moving HR to a higher level: HR practices and organizational effectiveness. In K. J. Klein, \& S. W. Kozlowski (Eds.), Multilevel theory, research, and methods in organizations: Foundations, extensions, and directions. San Francisco: Jossey-Bass.

Paul, A.K. \& Anantharaman, R.N. 2003 Impact of people management practices on organizational performance. International Journal of Human Resource Management, 14, 1246-1266.

Paauwe, J. 2004 HRM and performance: Achieving long-term viability. New York: Oxford University Press Inc.

Pfeffer, J. \& Cohen, Y. 1984 Determinants of internal labor markets in organizations. Administrative Science Quarterly, 29, 50-572.

Pfeffer, J. 1994 Competitive advantage through people: Unleashing the power of the work force. Boston, MA: Harvard Business School Press.

Pfeffer, J. 1998 The human equation. Boston, MA: Harvard Business School Press.

Poole, M. 1999 Human resource management. A critical perspective on business and management. London: Routledge, 1-3.

Poole, M. 1990 Human resource management in an international perspective. International Journal of Human Resource Management, 1(1), 1-15.

Schneider, B. 1990 Organizational climate and culture. The Josey_Bass Management Series.

Snell, A. S., Youndt, M. A., \& Wright, P. M. 1996 Establishing a framework for research in strategic human resource management Merging resource theory and organizational learning. Research in Personnel and Human Resource Management, 14, 61-90. 
Schuler, R. S. \& Jackson, S. E. 2005 A quarter-century review of human resource management in the U.S: The growth in importance of the international perspective. Management Review, 16-1, 1-25.

Schuler, R. S. \& Jackson, S. E. 1999 Strategic human resource management: $A$ reader. London: Blackwell.

Schuler, R. S. \& Jackson, S. E. 1987 Linking competitive strategy with human resource management practices. Academy of Management Executive, 3, 207219.

Takeuchi, N. \& Ziguang, C. 2001 Strategic transfer of HRM practices for competitive advantage: Implications for sequential transfer of Japanese HRM to China and Taiwan. Japanese Journal of Administrative Science, 15(2), 109-130.

Tichy, N, Fombrun, C. \& Devanna, M. A. 1982 Strategic human resource management. Sloane Management Review, 23(2), 47-61.

Tsui, A.S., Pearch, JL., Porter, L.W. \& Tripoli, A.M. 1997 Alternative approaches to employee-organization relationship: Does investment in employees pay off? The Academy of Management Journal, 40, 1089-1121.

Ulrich, D. \& Lake D. 1991 Organizational capability. Creating competitive advantage. Academy of Management Executives, 5(1), 77-92.

Von Bertalanffy, L. 1950 The theory of open systems in physics and biology. Science, 111, 23-29.

Walton, R. E. 1985: From control to commitment in the workplace. Harvard Business Review, 7-84.

Wright, P. M. \& McMahan, G. C. 1992 Theoractical perspectives for strategic human resource management. Journal of Management, 18, 295-320.

(Received March 16, 2007 Accepted January 16, 2008) 